\title{
The Influenceof Work Motivation on Teacher Performance of Vocational School in Medan City, Indonesia
}

\author{
Darmawati $^{1}$, Sri Melfayetti ${ }^{2}$, Selamat Triono Ahmad ${ }^{2}$ \\ ${ }^{1}$ Education and Teaching Faculty, University of Muhammadiyah Sumatera Utara (UMSU), Indonesia \\ ${ }^{2}$ State University of Medan (Unimed), Medan, Indonesia \\ email:_darma_wati65@yahoo.com \\ milfayetty@yahoo.com \\ selamattrionoahmad@gmail.com
}

\begin{abstract}
Based on the description on the background of the problem, that there are many that affect teacher performance. The results of the analysis of the Model of Organization Behavior's Integrative Model proposed by Colquit, Lepine, and Wesson which asserted that the individual outcomes considered to influence performance consisted of: job satisfaction, stress, motivation, trust, justice and ethics, and learning and decision making. And The formulation of the problem in this study is there any influence of work motivation on the performance of teachers SMK Medan City. The purpose of this study is to determine the magnitude of theinfluence of work motivation on the performance of teachers SMK Medan City. The research was conducted at 14 SMK Negeri in Medan city, there are SMKN 1, SMKN 2, SMKN 3, SMKN 4, SMKN 5, SMKN 6, SMKN 7, SMKN 8, SMKN 9, SMKN 10, SMKN 11, SMKN 12, SMKN 13, SMKN 14.The population of this research is Vocational High School (SMK) teacher in Medan city both public (civil servant) and private (Non PNS) which is 4,379 people with 367 samples taken by Slovin formula.The research instrument is a questionnaire with Likert scale.Research data is processedand analyzed by simple regression analysis.This simple regression analysis begins by testing the requirements analysis including normality test, linearity test and regression significance. The results of this study indicate that the influence of Work Motivation on Teacher Performance SMK Medan City of 5.1\%, while the rest influenced by other variables outside the variable in this study.
\end{abstract}

Keywords: work motivation; performance;

\section{Introduction}

Teachers are the most important factor in spurring the quality of education, so improving the quality of the teaching profession is a necessity. Professional educators have a set of competencies required to sustain their duties and functions as educators. Professional educators not only master the field of science, teaching materials, and methods, but also must be able to motivate learners, have a high skill and insight. Sardiman suggests that teachers are one of the human components in the teaching and learning process, which plays a role in the effort of forming potential human resources in the field of development. Therefore, teachers 
who are one element in the field of education must play an active role and put its position as professionals, in accordance with the growing demands of society. In this case the teacher is not solely as a teacher who transfers knowledge, but also as an educator who transfers values as well as mentors who provide direction and guide students in learning. However, data on the ground shows that there are still many problems faced in improving the quality and performance of vocational education teachers.

The quality of teacher performance in North Sumatera is still low, it can be seen from the result of Initial Competency Test (UKA) or Teacher Competency Test (UKG). North Sumatra is rated 25 out of 34 provinces, including in Medan. Jason A. Colquitt, Jeffery A. Lepine and Michael J. Wesson define Performance as follows: that performance is the behavior of employees who donated to achieve organizational goals. From these statements can be stated that the performance is declared successful if the goals of the organization can be achieved properly. Performance here links between the work with behavior. As a behavior, performance is a human activity directed to support the tasks assigned by the organization to it, the direction of the behavior is done by the organization through work reference, in the form of regulations, description of main tasks and work functions, and organizational authority, so that its behavior is directed and consistent with organizational goals, so that the work in accordance with the expected goals. The success of SMK in conducting its education can not be measured from the number of students who graduated or achievement, but how big the graduate of SMK can be channeled to fill the world of work. To achieve this, the vocational education institution should not only prioritize the development of an education system that is oriented towards the improvement of the quality of professional graduates, but the most important thing is to create teachers who have a strong work ethic, discipline and performance.

Djohar also posed challenges related to the quality of teachers in the form of personal, social, competence, profession, and teacher skills in performing their duties. These challenges include (1) teacher education system that does not guarantee the implementation of quality teacher education; (2) unclear management of teacher duties that ensure education can work well and proportionally; (3) performance standards that become measures of teacher performance are not clear to teacher education providers that result in actual performance of teachers when performing their daily tasks are not clear in size; and (4) quality assurance of teacher education is not representative. It is important for a teacher to have high performance as one of the keys to successful learning. Stoner asserts that performance can be assessed from two perspectives, namely efficiency and effectiveness of work. From the point of work efficiency refers to the correct completion of work and resources spent minimally possible, while work effectiveness refers to the completion of work correctly, and high cost. Based on this definition it appears that the effectiveness and efficiency covered by performance measures is an inseparable understanding, since the results obtained as a resource use are more efficient or effective.Thus, the description above describes various factors that are considered to influence the performance of teachers, both based on the description of theory and empirical facts of research, then in order to develop theoretical models and overcome the problems of teacher performance needs to be done research on the influence of work motivation on the performance of SMK Medan city. 


\section{Review of Literature}

\subsection{Teacher Performance}

The performance of teachers by Hugh J. Arnold and Daniel C Feldman is a set of behavior or individual activities/ teachers that match the expectations or desires of the organization in which they work. On the other hand, effective deeds and performance require some standards of individual performance comparison. Thus it appears clearly that every activity undertaken by teachers to form a performance that leads or wants to achieve the achievement of organizational goals that have been set before. According to Davis that: performance is the result of work that can be achieved by a person or group of people within an organization, in accordance with the authority and responsibility of each. Therefore, the organization of vocational schools can succeed well in its management and will relate to a number of different teacher characters. While Stephen P. Robbins, states that performance is the benchmark of success in doing a job. The benchmark of success in doing a job.So that the performance of the teacher will appear in the situation and conditions of daily work, in carrying out a job obtained as a result of its work.

Furthermore Colquitt, et al, that individual outcomes in the organization of one of them is performance. Individual outcomes are influenced by an individual mechanism consisting of; Job satisfaction, stress, motivation, trust, justice and ethics, and learning and decision making. Individual mechanisms are influenced by organizational mechanisms comprising, organizational culture and organizational structure, group mechanisms, consisting of leadership style and behavior, leadership power and influence, team processes, team characteristics, and individual characteristics, consisting of: personality and cultural values as well as capability. Newstrom states that factors affect performance in organizational behavior systems. In this system, there are philosophy, values, vision, mission, and management goals that affect the culture of the organization. Together with the social environment and organizational structure affect the leadership, communication and group dynamics. It then affects the quantity of work life and then affects motivation. Motivation will ultimately affect performance in terms of performance, satisfaction and personal growth. Individual performance is identified as a major factor in affecting the performance of a job. As Schermerhorn discloses that the performance equation can be written as follows:

\section{Performance $=$ Individual attributes $\mathbf{X}$ Work effort $\mathbf{X}$ Organizational support}

The equation describes performance as a result of the nature of the individual, the effort provided and the support received from the Institute. This means that all three factors must be maximally owned by each person to complete or complete the work that has been set. Each boss must understand how each factor works independently or together affect the outcome of the work. Performance gives an excellent experience in developing the potential that can be contributed to its work. This provides a simple method for measuring critically important behaviors that are essential for effectively managing others as follows: (1) Individual Data: Generates initial values in designing or planning an effective development program, for objective evaluations in collecting data regarding the advantages and disadvantages of individuals, create ease in making constructive changes. (2) Management Data: produces information used by managers in understanding the people they manage. (3) Factors Performance Indicators: productivity, quality of work, initiative, teamwork, problem 
solving, stress, motivation. Based on the theory and understanding of performance as described above, it can be formulated synthesis that the performance in this study is the performance of teachers to achieve the objectives, measured by using outcome indicators, work behavior, work skills and job mastery.

\subsection{Motivation}

Motivation (motivation) is basically derived from the word motive (motive) which means encouragement, cause or reason for someone to do something. Wuraji argues that the motivation concerning the matter of behavior, and motivation can be interpreted as a human effort to get the job done with enthusiasm, because he wanted to do it. Similar opinion was put forward by Chung \&Megginson in Gomes, "motivation is definied as goal-directed behavior. It is closely related to employee satisfaction and job performance. Based on several opinions about the definition of motivation put forward, it can be concluded that motivation is a good encouragement that comes from inside or outside that causes a person to do something. Motivation is very important because motivation is what causes, distributes, and supports human behavior in doing its work so as to achieve good results.

\section{Methods of Research}

The method used in this research is the method of quantitative approach in the form of expost facto research, ie the variables studied are not controlled and manipulated by the researcher, but the facts are expressed based on the measurement of symptoms that have been owned or test what happened. This research method analyze one variable with other variable used path analysis (path análysis). Path analysis requires the requirement of a significant linear regression relationship between variables. The population in this study is all the Vocational School Teachers (SMK) as Medan city, amounting to 4,379 people. A good sample is a representative sample that represents the population. The sample selection is done proportionally with random sampling by lottery with sample size adopting Slovin formula $\mathrm{N}$ $=\mathrm{N} /(1+(\mathrm{N} \times$ e2 $)$. Then obtained: $\mathrm{n}=4.379 /(1+(4.379 \times 0,052))=366,52$ people, rounded up to 367 Research instruments using questionners with Linkert scale.

\section{Results of Research}

Based on the statements of work motivation variable, the lowest score was 79 and the highest was 143. Average was 117.75, standard deviation 15,21, median 120, and 124 mode. average, median and mode are not much different, indicating that the distribution of data tends to be normally distributed. In accordance with the basic statistical calculation results, the data are classified using the Sturges rule into ten class intervals. the distribution of motivation scores of 133 people $(36.2 \%)$ was below the interval class average, 52 people $(14.2 \%)$ were in the interval class average and as many as 182 people $(49.6 \%)$ were above average . Based on the above data, the work motivation is generally above average. From the data it is concluded that the concentration of work motivation variable is leaning to the right. While the statement items of teacher performance variable obtained the lowest score is 76 and the highest is 135. Average 107.37, standard deviation 14.58, median 107.37 and mode 106. The distribution of this data indicates that the average score, median and mode are not much different, indicating that the distribution of data tends to be normally distributed. the teacher 
performance score of 168 people (148.8\%) was below the interval class average, 65 people $(17.7 \%)$ were in the interval class average and 134 people $(36.5 \%)$ were above the average, average. Based on the data above, the teacher performance is generally above average or categorized well. data concentration of teacher performance variables seen that the mean, median, and relative modes are the same. Then the median and mode values are in the same interval class on the left of the mean value. From the data, it is concluded that the concentration variable of teachers performance is leaning to the right.

On the test results tendency of work motivation high category $49.59 \%$, medium category of $43.32 \%$, category less by $7.08 \%$ and while the low category does not exist. Thus it can be concluded that the motivation of work in this study tends to be high as evidenced by $49.59 \%$ of respondents fall into the high category. And on the performance of high category teachers $26.98 \%$, medium category of $64.31 \%$, category less by $8.72 \%$ and while the low category does not exist. Thus it can be concluded that the Performance Teachers in this study tend to be mediated with $64.31 \%$ of respondents entered in the category of being. The results of the linearity test of teacher performance with work motivation can be seen from the following table;

\section{Table 1. Summary of Anava Test The linearity of teacher performance on work motivation}

\begin{tabular}{|l|c|c|c|c|c|}
\hline Varians & JK & Db & RJK & F $_{\text {hit }}$ & F $_{\text {tab }}$ \\
\hline Total & 4308765 & 367 & & & \\
\hline Reg (a) & 4230937 & 1 & 4230937 & & \\
\hline Reg (b) & 10558,2 & 1 & 10558,2 & 57, & 3,87 \\
\hline Sisa (S) & 67269,3 & 365 & 184,30 & & \\
\hline Galatt & 51208,6 & 55 & 931,07 & & \\
\hline Tuna & 16060,7 & 310 & 51,809 & 0,0 & 1,44 \\
\hline
\end{tabular}

By consulting Ftc with Ftable at $\alpha=5 \%$ and $\mathrm{db}$ numerator $=\mathrm{N}-\mathrm{K}=310$ and $\mathrm{db}$ denominator $=\mathrm{K}-2=55$ obtained Ftab $(310.55)=1.44$. Because Fhitung $<$ Ftabel $(310,55)$ is $0,06<1,44$ so it can be concluded that the teacher teacher performance regression equation $=$ $65,78+0,35$ work motivation is Linear. And Table 1 can also be seen that Fcount regression obtained 57.29 while the price Ftabel with dk numerator 1 and dk denominator 367 at significance level $\alpha=0.05$ is 3.87. It turns out that the price of Fhitung (57.29) is greater than the price of Ftable (3.87) it can be concluded that the coefficient of regression direction of SMK teacher performance on work motivation means at significance level $\alpha=0,05$. Regression teacher performance equation of SMK $=65,78+0,35$ of work motivation can then be accounted for to draw conclusion about relation between teacher performance with work motivation. This means that an increase of one job motivation score will increase by 0.35 score on the performance of vocational teachers in Medan city.

From the calculation of correlation test of work motivation with teacher performance obtained rhitung $=0,368$ while rtabel with $\mathrm{N}=367$ and $5 \%$ significance level equal to 0,102 . Thus the price $r_{-}\left(x_{-} y_{-}\right)>$rtabel $(0.368>0.102)$. Furthermore, the significance test of correlation by using t-test. With the price rhitung $=0.368$ obtained tcount $=7,569$. From the distribution list $\mathrm{t}$ with $\mathrm{dk}=365$ and $5 \%$ significance level obtained ttable $=1,652$. Thus the price rhitung $>$ rtabel $(0.368>0.102)$, then it can be said there is a significant correlation between Spiritual Leadership variable with work stress. From the distribution list $\mathrm{t}$ with $\mathrm{dk}=$ 365 and 5\% significance level obtained ttable $=1,652$. Thus it turns out that thitung >ttable 
(7.569> 1.658) so it can. it is concluded that there is a significant correlation between the variables of work motivation and teacher performance. From the calculation results can be concluded that between Work Motivation and Performance teacher there is significant and significant correlation.

\section{Discussion}

The result of the test of the tendency of work motivation variable is high category $49,59 \%$, medium category $43,32 \%$, category less equal to $7.08 \%$ and while low category does not exist, hence can be concluded that work motivation in this research tends to high $49.59 \%$ of respondents fall into the high category. While the results of the test tendency of teacher performance variable high category $26.98 \%$, medium category of $64.31 \%$, category less by $8.72 \%$ and while the low category does not exist, thus it can be concluded that teacher performance in this study tends to be proven with $64.31 \%$ of respondents included in the medium category. And the results of the hypothesis of the research showed that statistically the hypothesis proposed has been proven positively and significantly has an influence between the variables used as exogenous variables to endogennnya variable.Direct Influence Work Motivation on Teacher Performance of $0.2262=0.051$. Thus, work motivation that directly determines teachers' performance changes is $5.1 \%$. Motivation of work is the impetus of a teacher to do a job in achieving the desired goals. While the performance of teachers is the performance of teachers in performing daily tasks in school.The motivation that teachers have, whether from within themselves or from outside, becomes the determinant of the actions of teachers in the school. Work motivation will maximize the potential it has to improve its performance in schools. Teacher performance is strongly influenced by teachers' work motivation. It is highly unlikely that someone who does not have a strong motivation can work effectively, so it can be said that good teacher work motivation will improve the performance of good teachers as well.

\section{Conclusion}

Based on the results of research indicate that the direct influence of work motivation on the performance of SMK teachers in Medan City is 5.1\%. The results of this study provide assertion that to get teachers who are expected to contribute positively to all activities of schools or organizations in achieving its goals, each teacher is expected to have high work motivation which is expected later will improve its high performance. Motivation is very important to be considered by the management if they want every teacher can contribute positively to the achievement of high teacher performance, because with motivation, a teacher will have a high spirit in carrying out the tasks assigned to him. Without motivation, a teacher can not fulfill his duties according to standard or even exceed the standards because what is his motive and motivation in work is not fulfilled. Even if a teacher has good operational skills if he / she has no motivation to work, the end result of his work will not be satisfactory. Given the importance of motivation, then the form of attention of the management in this case the principal conducts business motivation through a series of specific efforts in accordance with the policy, so that the motivation of teachers in work will be maintained. To motivate teachers, the principal must know the motives and motivations desired by teachers. In 
summary, motivation is a very important problem in an organization, because it can improve teacher performance. So the management ability of the leadership in providing motivation will determine the success or failure in achieving the performance and goals of the organization or school.

\section{References}

A.M. Sardiman. Interaksi Dan MotivasiBelajarMengajar. (Jakarta: PT. GrafindoPersada, 2005), hal.125.

Jason A. Colquitt, Jeffery A. Lepinedan Michael J. Wesson, Organizational Behavior : Improving Performance and Commitment in the Work Place.(New Jersey New York :McGraw-Hill, 2009), hal. 57.

Djohar. Guru: PendidikandanPembinaannya. (Yogyakarta: GrafikaIndah, 2006), hal. 45.

James A.F Stoner dan R. Edward Freeman. Management.(New Jersey: Prentice Hall International, Inc., 1992), h.6.

Hugh J. Arnold and Daniel C. Feldman.Organization Behavior.(New York: McGraw-Hill Book Company, 1986), hal. 24.

William B Westher Jr. dan Keith Davis. Human Resources and Personnel Management.(New York: McGraw Hill, 1996), hal.341.

Stephen P. Robbins. Essential of Organizational Behavior (New Jersey : Prentice-Hall Inc, 2000), hal. 218.

Jason A. Colquitt, Jeffery A. Lepinedan Michael J. Wesson, Op Cit. hal. 8.

John W. Newstrom.Organizational Behavior : Human Behavior at Work.(USA McGraw Hill Companies Inc, 2007), hal. 26.

Schermerhorn, Jr., et al. Op. Cit, hal. 147.

http : // www.hiresmart. com/system/performance, 1998, h.1

HadariNawawi. ManajemenSumberDayaManusia. (Yogyakarta: Gajah Mada UniversityPress, 2005), hal.351.

Wuraji. SosiologiPendidikan. SebuahPendekatanAntropologi.(Jakarta: DirjenDiktiDepdikbud, 1988), hal.24.LihatJuga T. Hani Handoko.Manajemen.(Yogyakarta: BPFE, 1997), hal.56, danWahjosumidjo.KepemimpinanKepalaSekolah.(Jakarta: Rajawali Press, 2008), hal. 23.

Faustino Cardoso Gomes. ManajemenSumberDayaManusia. (Yogyakarta: Andi Offset, 2003), hal.177.

Umar Husein. MetodePenelitianuntukSkripsi, Tesis, Bisnis.(Jakarta:RajaGrafindo, 1996), hal. 78 